Key words heuristic education, strategies and techniques of heuristic education, professional and creative self-realization, future teacher, educational products, constructive and creative techniques.

удк 378.147:796-051]:005.336.2-027.561:37.013.321

Михайло Лянной

Сумський державний педагогічний

університет імені А.С. Макаренка

ORCID ID 0000-0002-7128-072X

DOI 10.24139/2312-5993/2020.09/193-203

\title{
ТЕОРЕТИКО-МЕТОДИЧНІ ЗАСАДИ РОЗВИТКУ ПРОФЕСІЙНОЇ КОМПЕТЕНТНОСТІ МАЙБУТНІХ ФАХІВЦІВ 3 ФІЗИЧНОЇ КУЛЬТУРИ І СПОРТУ В УМОВАХ ІНФОРМАЛЬНОЇ ОСВІТИ
}

У статті окреслено теоретичні та методичні засади розвитку профресійної компетентності майбутніх фрахівців з фізичної культури і спорту в умовах інформальної освіти, що забезпечує самостійну й ефективну реалізацію цілей педагогічного прочесу. Зазначено, що інформальна освіта майбутніх фахівців з фрізичної культури і спорту відбувається в інтеграції з формальною і неформальною в різних поєднаннях. Виявлено основні переваги інформальної освіти в контексті професійної підготовки майбутніх фрахівців з фрізичної культури і спорту над формальною і неформальною, яка проявляється в орієнтації на самореалізацію, зосередженні на особистісному самовдосконаленні здобувачів освіти і подальшому управлінні власним освітнім простором.

Ключові слова: професійна компетентність, майбутні фрахівці, фрізична культура і спорт, інформальна освіта, фізкультурно-спортивна діяльність.

Постановка проблеми. В умовах сучасного розвитку освіти на перший план виходить підготовка випускників, які володіють навичками і здібностями соціально-психологічної та професійної адаптації в швидкоплинному світі. Державні освітні стандарти вищої освіти України істотно актуалізують питання розвитку професійної компетентності майбутнього фахівця $з$ фізичної культури і спорту. Основна проблема професійної підготовки майбутніх фахівців з фізичної культури і спорту детермінується спрямуванням більшою мірою на формування комплексу знань, умінь і навичок, що призводить до того, що фахівець, будучи добре поінформованим і теоретично підкованим професіоналом, не здатний застосувати отриману інформацію на практиці. Рішенням даної проблеми стає впровадження в освітній процес інновацій, форм і засобів, що дозволяють змістити акценти, з одного боку, на практичну орієнтованість програм вищої освіти, з іншого, - на самостійність, самоорганізованість, самоосвіту й саморозвиток студента (інформальна освіта), що передбачає формування у нього високого ступеня особистісної мотивації до оволодіння цілою низкою затребуваних сьогодні компетентностей (Портнова и др., 2019). 
Традиційна система освіти, яка найчастіше представлена формальним та неформальним видами, не відповідає потребам і викликам сучасності й гальмує розвиток потенційних можливостей здобувачів освіти. Саме тому в останні десятиліття значна увага приділяється інформальній освіті, значення і необхідність якої значно підвищилися в освітньому процесі вищої школи. 3 урахуванням того, що саме інформальна освіта сприяє формуванню життєвих установок здобувачів освіти, заповнює дефіцит професійної компетентності, виникає необхідність осмислення їі актуальності в контексті професійної підготовки майбутніх фахівців з фізичної культури і спорту.

Аналіз актуальних досліджень. Значний внесок у розробку проблеми професійної підготовки майбутніх фахівців з фізичної культури і спорту зробили вітчизняні науковці Н. Міцкевич, Л. Сущенко, О. Томенко, Ю. Биков, І. Струнін, В. Чічкін, П. Рибалко, А. Кашуба та ін. Питаннями розвитку професійної компетентності майбутніх фахівців з фізичної культури і спорту займалися В.Лозова, О. Пометун, М. Степка, А. Хуторський, І. Маріонда, Е. Сивохоп, А. Товт, І. Іваній та ін.

Складністю визначення й вимірювання інформальної освіти пояснюється майже повна відсутність фундаментальних теоретичних досліджень такої форми освіти. Частково проблема використання інформальної освіти у професійній підготовці майбутніх фахівців представлена в дослідженнях О. Жихорьської, Т. Кристопчук, В. Лугового, В. Халецької, О. Щербини. Вищевказані науковці вважають, що саме інформальна освіта може ефективно вирішувати завдання професійної підготовки, заповнення дефіциту її професійної компетентності. У середовищі зарубіжних дослідників питаннями інформальної освіти займалися H. Pokorny, R. Whittaker, H. Gibson, R. Whittaker.

Метою статті $\epsilon$ визначення теоретичних і методичних засад розвитку професійної компетентності майбутніх фахівців з фізичної культури і спорту в умовах інформальної освіти, що забезпечить самостійну й ефективну реалізацію цілей педагогічного процесу.

Методи дослідження: використано теоретичний аналіз науковометодичної літератури з визначеної проблематики, порівняння й узагальнення даних, зіставлення різних поглядів на проблему дослідження.

Виклад основного матеріалу. Майбутній фахівець з фізичної культури і спорту трактується П. Рибалко як «особистість, яка цілеспрямовано здобуває в закладах вищої освіти кваліфікацію відповідно до певного освітньо-кваліфікаційного рівня в процесі спеціально організованої навчально-виховної діяльності, спрямованої на підготовку до 
подальшої професійної діяльності щодо підтримки відповідного рівня фізичної культури населення або досягнення вищих спортивних результатів на олімпійській, світовій чи регіональній аренах у командному чи в індивідуальному вимірах» (Рибалко, 2019).

У контексті дослідження також доцільно розглянути поняття «професійної компетентності» та «інформальної освіти».

А. Маркова дає таке визначення професійної компетентності. Професійна компетентність - це «індивідуальна характеристика ступеня відповідності вимогам професії, психічний стан, що дозволяє діяти самостійно й відповідально, володіння людиною здатністю і вмінням виконувати певні професійні функції». А. Самусік під професійною компетентністю розуміє «систему показників оволодіння майстерністю в певній галузі професійної діяльності» (Маркова, 1996).

У загальному вигляді професійну компетентність визначають як сукупність якостей особистості, що забезпечують ефективну професійну діяльність. Особистісні якості включають: професійно важливі знання, уміння та навички; професійні здібності; професійну спрямованість; досвід творчої професійної діяльності та мислення. їх інтеграція являє собою єдність теоретичної і практичної готовності до визначеної професійної діяльності й дозволяє фахівцю проявити на практиці здатність реалізувати свій потенціал для успішної творчої професійної діяльності.

С. Хазова у своїх дослідженнях наголошує, що професійна компетентність фахівців з фізичної культури і спорту включає «систему загальних і спеціальних психолого-педагогічних знань і вмінь, необхідних для ефективного здійснення навчально-виховної діяльності; економікоуправлінську і правову підготовку, що дозволяє виконувати індивідуально й готувати вихованців до виконання різних соціальних ролей; сформоване цілісне професійне мислення і свідомість, що зумовлюють успішність творчої професійно-педагогічної діяльності» (Хазова, 2010).

Таким чином, формування професійних компетенцій фахівця 3 фізичної культури і спорту починається з моменту перших занять спортом і триває в процесі навчання за фахом і подальшої діяльності.

Професійну компетентність фахівця з фізичної культури і спорту можна поділити на такі види:

- гностична, що відображає вміння аналізувати спеціальну літературу, виокремлювати важливе, виконувати узагальнення; адекватно оцінювати стан спортсменів, знаходити причини помилок і ускладнень; рефлексією власної діяльності та діяльності підопічних; 
- проєктувальна, що забезпечує стратегічну спрямованість діяльності викладача/тренера, що виявляється в умінні орієнтуватися на кінцеву мету, вирішувати актуальні завдання з урахуванням специфіки майбутньої спортивної діяльності підопічних і встановлювати необхідні взаємозв'язки своїх психолого-педагогічних впливів з усіма складовими їх розвитку;

- конструктивна, яка забезпечить реалізацію тактичних цілей, вибір адекватних форм проведення занять, визначення найбільш раціональних способів діяльності й точне дотримання закономірностей планування змісту занять;

- організаторська, що є реалізацією на практиці проєктів і планів, а також умовою цілеспрямованого й реального проєктування педагогічних завдань;

- комунікативна, що забезпечує обмін інформацією між учасниками тренувального та освітнього процесів.

Інформальну (або позаінституційну) освіту можна трактувати як «індивідуальну пізнавальну діяльність, яка супроводжує повсякденне життя і не обов'язково носить цілеспрямований характер» (Вершловский), коли доросла особа перетворює освітні потенціали суспільства на дієві фактори свого розвитку (Лискина та Паульзен, 2018).

Ю. Гібадуліна визначає інформальну освіту як «нецілеспрямований, стихійний (спонтанний), ненавмисний процес отримання знань, умінь та навичок. Вона здійснюється на робочому місці, у колі сім'ї або на відпочинку - у повсякденному житті, без освітніх формальностей. Інформальна освіта не веде до сертифікації» (Гибадуллина, 2014). О. Шувалова трактує дане поняття як «індивідуальне навчання (самоосвіту), що на відміну від формальної освіти і додаткової освіти здійснюється самостійно й не фіксується в дипломі або іншому документі, але робить внесок у розширення знань та вмінь» (Шувалова, 2010).

Розширення в XXI ст. освітнього простору призвело виникнення інформальної освіти як відповіді на динамічні зміни в усіх сферах житєдіяльності людини. Його актуальність у сучасних умовах життя і професійної діяльності пов'язана з пошуком інших стратегій забезпечення якості професійної підготовки здобувачів освіти у вищій школі. Постійне нарощування кваліфікації, підвищення професійного рівня в межах раніше набутої професії, а також придбання нових компетентностей необхідні сучасному конкурентоспроможному фахівцю. Інвестування у власний професійний розвиток підвищує їх конкурентоспроможність, дозволяє максимально реалізувати свій потенціал (Меморандум непрерывного образования EC, 2000). 
Аналіз науково-педагогічної літератури показує, що в сучасних умовах відсутні масштабні наукові дослідження, спрямовані на розробку концептуальних основ інформальної освіти. Найчастіше вивчення інформальної освіти відбувається в інтеграції 3 формальною та неформальною в різних поєднаннях.

Формальна освіта розглядається науковцями як процес отримання знань, що відбувається в організованому та ієрархічно впорядкованому контексті, і завершується видачею документа державного зразка диплома про початкову/середню професійну або вищу освіту або атестата. Даний процес має встановлену за різними програмами тривалість, що базується на державній навчальній програмі та державних освітніх стандартах, який організований переважно формальними, зареєстрованими організаціями (Бугайчук, 2013).

Неформальна освіта трактується як процес отримання нових професійно-орієнтованих знань, що відбувається поза межами спеціалізованого освітнього простору, при цьому існують конкретні цілі, методи й методики, а головне, - результат навчання. Може проводитися освітніми або громадськими організаціями, різними клубами і кружками, секціями, під час навчання з викладачем або тренером індивідуально, і являє собою різноманітні тренінги, курси, семінари, круглі столи, які супроводжуються видачею документа, що підтверджує додаткове підвищення кваліфікації - сертифікат учасника, диплом підвищення кваліфікації, свідоцтво, тощо (яблоков, 2018).

Основна відмінність інформальної освіти від формальної і неформальної полягає в тому, що процес набуття професійно орієнтованих знань, умінь і навичок проходить не в установах системи освіти, а в інших соціальних інститутах (у родині, на тренуванні, на роботі, в інших формальних і неформальних об'єднаннях). Процес $є$ багатоплановим, а його структура збігається зі структурою життєдіяльності людини. Незважаючи на відсутність систематизації видів інформальної освіти, до основних ії видів належить навчання методом проб і помилок, стихійна самоосвіта, взаємоосвіта під час спільної діяльності, отримання інформації із засобів масової інформації, робота під керівництвом досвідченого фахівця, заняття аматорською художньою діяльністю тощо (Гаврилова та Запруднова, 2016).

Натепер можна зустріти велику різноманітність визначень, концепцій, що стосуються інформальної освіти, що свідчить про те, що дане питання $\epsilon$ дискусійним і актуальним. Це відносно нова модель професійного розвитку, яка затребувана саме здобувачами освіти, оскільки форми інформальної 
освіти спрямовані саме на суб'єкта освіти, ураховують його особисті інтереси і потреби, зосереджені на його особистісному зростанні.

До видів інформальної освіти у процесі професійної підготовки майбутніх фахівців з фізичної культури і спорту можна віднести:

- навчання за методом проб і помилок під час фізкультурноспортивної діяльності;

- стихійна або свідома самоосвіта у вигляді самостійного пошуку відповідей на актуальні професійні питання або способів вирішення практично-значущих проблем у сфері фізичної культури і спорту;

- взаємоосвіта під час спільного виконання тих чи інших завдань тренувально-змагальної діяльності;

- отримання нових знань за допомогою сучасних інформаційних технологій (інтернет, бази даних та ін.) і через засоби масової інформації;

- збагачення духовного світу через читання і відвідування закладів культури (читання відіграє не тільки освітню функцію, але й активно впливає на саморозвиток і самоідентифікацію особистості, виконуючи функцію самовиховання);

- виконання фізкультурно-спортивної діяльності під керівництвом компетентного тренера/фахівця/педагога тощо;

- розвиток комунікативних навичок і становлення світогляду в процесі міжособистісного спілкування;

- розширення кругозору, збагачення духовного світу і придбання життєво важливих знань, умінь, навичок у процесі пізнавальної, організаторської, пропагандистської, інструктивно-педагогічної, суддівської діяльності.

Визначення місця і значення інформальної освіти в освітньому процесі майбутніх фахівців з фізичної культури і спорту у вищій школі також не складає труднощів, оскільки його значення постійно зростає. Так, визначаючи місце інформальної освіти в процесі навчання студента фізкультурного профілю, відзначимо, що навчальним планом освітньої програми на самостійну роботу з кожної дисципліни формально виділяється певна кількість годин. Створюються умови для досягнення максимально ефективного результату в межах цього виду навчання: розробляються методичні матеріали (робочі програми, силабуси); збільшується доступність спеціального спортивного обладнання для покращення власної спортивної досконалості. Оскільки інформальна освіта майбутніх фахівців з фізичної культури і спорту нерозривно пов'язана з формальним і неформальним навчанням, нам представляється можливим розмежувати ці види освіти, 
спираючись на офіційні документи Міністерства освіти і науки України, власний професійний досвід і авторські позиції провідних науковців, що присвятили свої дослідження неперервній освіті (табл. 1).

Таблиця 1

Порівняльна характеристика видів неперервної освіти майбутніх фахівців з фізичної культури і спорту

\begin{tabular}{|c|c|c|c|c|}
\hline $\begin{array}{l}\text { № } \\
\text { ח/ח }\end{array}$ & $\begin{array}{l}\text { Ознаки } \\
\text { порівняння }\end{array}$ & Формальна освіта & $\begin{array}{l}\text { Неформальна } \\
\text { освіта }\end{array}$ & Інформальна освіта \\
\hline 1 & Мета навчання & $\begin{array}{l}\text { Розвиток / } \\
\text { удосконалення } \\
\text { професійних } \\
\text { компетентностей у } \\
\text { процесі } \\
\text { підвищення } \\
\text { кваліфікації } \\
\text { або професійної } \\
\text { перепідготовки }\end{array}$ & $\begin{array}{l}\text { Ліквідація } \\
\text { професійних } \\
\text { дефіцитів } \\
\text { рахунок } \\
\text { отримання } \\
\text { додаткових знань, } \\
\text { умінь, досвіду } \\
\text { практичної } \\
\text { діяльності }\end{array}$ & $\begin{array}{l}\text { Іноді мета відсутня, } \\
\text { визначається } \\
\text { здобувачами освіти } \\
\text { самостійно з } \\
\text { урахуванням } \\
\text { власних } \\
\text { особистісних і } \\
\text { професійних } \\
\text { інтересів }\end{array}$ \\
\hline 2 & Місце навчання & $\begin{array}{l}\text { Освітні організації } \\
\text { (державні / } \\
\text { недержавні, } \\
\text { установи } \\
\text { додаткової } \\
\text { професійної } \\
\text { освіти), що мають } \\
\text { ліцензію на право } \\
\text { здійснення освіт- } \\
\text { ньої діяльності та } \\
\text { пройшли проце- } \\
\text { дуру державної } \\
\text { акредитації }\end{array}$ & $\begin{array}{l}\text { Освітні і } \\
\text { громадські } \\
\text { організації (центри, } \\
\text { клуби, заняття } 3 \\
\text { репетитором, } \\
\text { короткострокові } \\
\text { програми, тренінги } \\
\text { та ін.) }\end{array}$ & $\begin{array}{l}\text { Поза освітніми } \\
\text { організаціями, у } \\
\text { повсякденній } \\
\text { практичній } \\
\text { діяльності }\end{array}$ \\
\hline 3 & $\begin{array}{l}\text { Нормативне } \\
\text { регулювання }\end{array}$ & $\begin{array}{l}\text { Закон України } \\
\text { «Про вищу освіту», } \\
\text { професійні освітні } \\
\text { стандарти, освітні } \\
\text { програми, } \\
\text { навчально- } \\
\text { планувальна } \\
\text { документація та } \\
\text { ін. }\end{array}$ & Договір & $\begin{array}{l}\text { Відсутність } \\
\text { нормативно- } \\
\text { правового } \\
\text { регулювання }\end{array}$ \\
\hline 4 & $\begin{array}{l}\text { Суб'єкти } \\
\text { педагогічного } \\
\text { процесу }\end{array}$ & $\begin{array}{l}\text { Професорсько- } \\
\text { викладацький } \\
\text { склад } \\
\text { (педагоги, які } \\
\text { відповідають } \\
\text { вимогам } \\
\text { нормативних } \\
\text { документів і }\end{array}$ & $\begin{array}{l}\text { Різні фахівці, } \\
\text { для яких немає } \\
\text { вимог до } \\
\text { здійснення } \\
\text { педагогічної } \\
\text { діяльності (у тому } \\
\text { числі педагоги) }\end{array}$ & $\begin{array}{l}\text { Міжособистісне } \\
\text { оточення, } \\
\text { соціокультурне } \\
\text { середовище }\end{array}$ \\
\hline
\end{tabular}




\begin{tabular}{|c|c|c|c|c|}
\hline & & $\begin{array}{l}\text { допущенні до } \\
\text { здійснення } \\
\text { педагогічної } \\
\text { діяльності) }\end{array}$ & & \\
\hline 5 & Термін навчання & $\begin{array}{l}\text { Терміни } \\
\text { регламентовані, } \\
\text { обмежені } \\
\text { часом, } \\
\text { навчання } \\
\text { розкладом } \\
\text { протягом повного } \\
\text { дня в } \\
\text { залежності від } \\
\text { виду навчання } \\
\text { (курси } \\
\text { підвищення } \\
\text { кваліфікації } \\
\text { або професійна } \\
\text { перепідготовка) }\end{array}$ & $\begin{array}{l}\text { Терміни не } \\
\text { регламентовані, } \\
\text { гнучкий графік, } \\
\text { можливість } \\
\text { припинення } \\
\text { навчання в } \\
\text { будь-який період }\end{array}$ & $\begin{array}{l}\text { Відбувається } \\
\text { безперервно всюди } \\
\text { і завжди }\end{array}$ \\
\hline 6 & $\begin{array}{l}\text { Обов'язковість } \\
\text { навчання }\end{array}$ & Обов'язкове & $\begin{array}{l}\text { Здійснюється } \\
\text { усвідомлено, } \\
\text { добровільним за } \\
\text { високого ступеня } \\
\text { зацікавленості } \\
\text { здобувачів освіти }\end{array}$ & $\begin{array}{l}\text { Здійснюється як } \\
\text { усвідомлено, так і } \\
\text { неусвідомлено, де } \\
\text { головним сенсом } \\
\epsilon \text { особистісне } \\
\text { зростання і } \\
\text { подальше } \\
\text { управління } \\
\text { власним освітнім } \\
\text { простором }\end{array}$ \\
\hline 7 & $\begin{array}{l}\text { Результати } \\
\text { навчання }\end{array}$ & $\begin{array}{l}\text { Отримання } \\
\text { документа } \\
\text { державного } \\
\text { зразка } \\
\text { (посвідчення, } \\
\text { диплом) }\end{array}$ & $\begin{array}{l}\text { Отримання або } \\
\text { відсутність } \\
\text { документа, } \\
\text { що підтверджує } \\
\text { факт навчання; } \\
\text { задоволення } \\
\text { професійних } \\
\text { інтересів } \\
\text { особистісних } \\
\text { потреб }\end{array}$ & $\begin{array}{l}\text { Відсутність } \\
\text { документа, } \\
\text { що підтверджує } \\
\text { факт навчання; } \\
\text { вирішення } \\
\text { особистісних } \\
\text { професійних } \\
\text { труднощів } \\
\text { фокусуванням } \\
\text { на свій або чужий } \\
\text { досвід, який } \\
€ \text { джерелом } \\
\text { навчання }\end{array}$ \\
\hline 8 & $\begin{array}{l}\text { Умови, що } \\
\text { регламентують } \\
\text { процес навчання }\end{array}$ & $\begin{array}{l}\text { Процедура зара- } \\
\text { хування (наявність } \\
\text { наказів в освітній } \\
\text { організації), здобу- } \\
\text { вачі освіти закріп- } \\
\text { люються за конк- } \\
\text { ретними групами }\end{array}$ & $\begin{array}{l}\text { Договірна } \\
\text { (недоговірна) } \\
\text { система } \\
\text { зарахування, } \\
\text { здобувачі освіти } \\
\text { включені в спільну } \\
\text { освітню діяльність }\end{array}$ & $\begin{array}{l}\text { Не } \\
\text { регламентується, } \\
\text { добровільна участь }\end{array}$ \\
\hline
\end{tabular}


Педагогічні науки: теорія, історія, інноваційні технології, 2020, № 9 (103)

\begin{tabular}{|l|l|l|l|l|}
\hline 9 & $\begin{array}{l}\text { Супровід після } \\
\text { навчання }\end{array}$ & Відсутній & Саморегуляція & $\begin{array}{l}\text { Самоосвіта, } \\
\text { саморегуляція }\end{array}$ \\
\hline 10 & $\begin{array}{l}\text { Контроль } \\
\text { навчання }\end{array}$ & Зовнішній & Самоуправління & Саморегуляція \\
\hline
\end{tabular}

Таким чином, із даних таблиці 1 можна зробити висновок про явні переваги інформальної освіти в контексті професійної підготовки майбутніх фахівців з фізичної культури і спорту над формальною і неформальною, яка проявляється в орієнтації на самореалізацію, зосередженні на особистісному самовдосконаленні здобувачів освіти й подальше управління власним освітнім простором; урахуванні особистих інтересів, бажань, потреб, можливостей; міжособистісній взаємодії, яка насичує соціокультурне середовище; інформальна освіта $\epsilon$ гнучкою, мобільною, загальнодоступною, не залежить від статі, віку, вона здатна задовольнити особистісні та професійні інтереси з фокусуванням на особистий або чужий досвід, який є джерелом навчання; від інших видів безперервної освіти інформальну освіту відрізняє високий ступінь саморегуляції (самоконтроль, самоаналіз, самоосвіта та ін.).

Висновки та перспективи подальших наукових розвідок. Дедалі більше значення інформальної освіти в освітньому процесі вищої школи підкреслює той факт, що все перераховане вище дозволяє майбутнім фахівцям з фізичної культури і спорту досяти кращого теоретичного і практичного рівня знань у сфері фізичної культури і спорту та високого рівня власної спортивної досконалості. Розглядаючи інформальну освіту як елемент цілісної безперервної освітньої системи майбутніх фахівців з фізичної культури і спорту, очевидно, що вона має внутрішню складну структуру і збагачує/доповнює формальну і неформальну освіту. Установлено, що інформальна освіта в контексті розвитку професійної компетентності майбутніх фахівців з фізичної культури і спорту має свою структуру, що потребує детального та комплексного дослідження та значний потенціал для професійно-особистісного росту вищевказаних фахівців. Саме в процесі інформальної освіти відбувається становлення професійних якостей особистості та їх подальший розвиток. Перспективою подальших наукових розвідок стануть вивчення й аналіз структури та функцій інформальної освіти в контексті професійної підготовки майбутніх фахівців з фізичної культури та спорту.

\section{ЛІТЕРАТУРА}

Бугайчук, К. Л. (2013). Формальное, неформальное и информальное дистанционное обучение. Материалы XX юбилейной конференции представителей региональных научно-образовательных сетей RELARN-2013, 114-121 (Buhaichuk, K. L. (2013). Formal, non-formal and informal distance learning. $M$ aterials of the $X X$ anniversary conference of representatives of regional scientific and educational networks RELARN-2013, 114-121). 
Вершловский, С. Г. Непрерывное образование как фрактор социализации. Режим доступа: http://www.znanie.org/jornal/n1_01/nepreriv_obraz.html. (Vershlovskii, S. G. Continuing education as a factor of socialization. Retrieved from: http://www .znanie.org/jornal/n1 01/nepreriv obraz.html).

Гаврилова, И. В., Запруднова, Л. А. (2016). Формальная, неформальная и информальная модели образования. Молодой ученый, 10 (114), 1197-1200 (Gavrilova, I. V., Zaprudnova, L. A. (2016). Formal, non-formal and informal models of education. Young Scientist, 10 (114), 1197-1200).

гибадуллина, Ю. М. (2014). Профессиональная подготовка педагогов в процессе интеграции формального, неформального и информального образования. Фундаментальные исследования, 11-10, 2253-2257 (Gibadullina, Yu. M. (2014). Professional training of teachers in the process of integrating formal, non-formal and informal education. Basic Research, 11-10, 2253-2257).

Лискина, Т. В., Паульзен, Н. С. (2018). Современные подходы к определению понятия «информальное образование». Известия Байкальского государственного универсumema, 1, 131-137 (Liskina, T. V., Paulsen, N. S. (2018). Modern approaches to the definition of the concept of "informal education". Bulletin of the Baikal State University, 1, 131-137).

Маркова, А. К. (1996). Психология профессионализма. Москва: Знание (Markova, А. К. (1996). Psychology of professionalism. M oscow: Knowledge).

Меморандум непрерывного образования EC 2000 2. Режим доступа: http://www.znanie.org/ docs/ memorandum.html. (Memorandum of Continuing Education EU 2000. Retrieved from: http://www.znanie.org/ docs/ memorandum.html).

Портнова, К. И., Бычкова, Н. В., Волков, В. В. (2019). Формирование управленческих компетенций будущих специалистов профессионального обучения в системе высшего образования. Наука, образование, культура, 2, 86-91 (Portnova, K. I., Bychkova, N. V., Volkov, V. V. (2019). Formation of managerial competencies of future vocational training specialists in the higher education system. Science, education, culture, 2, 86-91).

Рибалко, П. (2019). Особливості професійної підготовки майбутніх учителів фізичної культури до подальшої фахової діяльності. Педагогічні науки: теорія, історія, інноваційні технології, 9 (93), 235-244 (Rybalko, P. (2019). Peculiarities of professional training for physical culture teachers up to their own faculty. Pedagogical sciences: theory, history, innovation technologies, 9 (93), 235-244).

Хазова, С. А. (2010). Компетентность конкурентоспособного специалиста по физической культуре и спорту. Москва: Академия естествознания (Khazova, S. A. (2010). Competence of a competitive specialist in physical culture and sports. Moscow: Academy of Natural Sciences).

Шувалова, О. Р. (2010). Международные индикаторы участия населения в непрерывном образовании. Москва (Shuvalova, O. R. (2010). International indicators of population participation in lifelong learning. M oscow).

яблоков, С. (2018). Інтеграція формального, неформального та інформального навчання в навчанні англійської мови. Педагогічні науки: теорія, історія, інноваційні технології, 1 (75), 106-123 (Yablokov, S. (2018). Integration of formal, informal and informal education in English language teaching. Pedagogical sciences: theory, history, innovation technologies, 1 (75), 106-123). 


\section{PEЗЮME}

Лянной Михаил. Теоретико-методические основы развития профессиональной компетентности будущих специалистов по физической культуре и спорту в условиях информального образования.

В статье обозначены теоретические и методические основы развития профессиональной компетентности будущих специалистов по физической культуре и спорту в условиях информального образования, что обеспечивает самостоятельную и эффрективную реализацию целей педагогического прочесса. Отмечено, что информальное образование будущих специалистов по физической культуре и спорту происходит в интеграции с формальным и неформальным в различных сочетаниях. Выявлены основные преимущества информального образования в контексте профессиональной подготовки будущих специалистов по физической культуре и спорту над формальным и неформальным, которое проявляется в ориентации на самореализацию, сосредоточено на личностном самосовершенствовании соискателей образования и последующем управлении собственным образовательным пространством.

Ключевые слова: профессиональная компетентность, будущие специалисты, физическая культура и спорт, информальное образование, физкультурноспортивная деятельность.

\section{SUMMARY}

Liannoy Mykhailo. Theoretical and methodological foundations for the development of professional competence of future specialists in physical culture and sports in the context of informal education.

The article outlines the theoretical and methodological principles of developing professional competence of future specialists in physical culture and sports in the context of informal education, which provides independent and effective implementation of the goals of the pedagogical process. It is noted that informal education of future specialists in physical culture and sports takes place in integration with formal and non-formal education in various combinations. The main advantages of informal education in the context of professional training of future specialists in physical culture and sports over formal and non-formal are given, which are manifested in the focus on self-realization, personal self-improvement of students and further management of their own educational space. Theoretical analysis of scientific and methodological literature on certain issues, comparison and generalization of data, comparison of different views on the research problem is used. The professional competence of specialists in physical culture and sports includes "a system of general and special psychological and pedagogical knowledge and skills necessary for the effective implementation of educational activities; economic and managerial and legal training, which allows performing individually and preparing students to perform various social roles; formed a holistic professional thinking and consciousness, which determine the success of creative professional and pedagogical activities. Informal education is manifested in accounting for personal interests, desires, needs, opportunities; interpersonal interaction, which saturates the socio-cultural environment; informal education is flexible, mobile, accessible, regardless of gender, age, it is able to satisfy personal and professional interests with a focus on personal or other people's experience, which is a source of learning; informal education is distinguished from other types of continuing education by a high degree of self-regulation (self-control, self-analysis, self-education, etc.).

Key words professional competence, future specialists, physical culture and sports, informal education, physical culture and sports activities. 